ISSN 0258-7122 (Print), 2408-8293 (Online)

Bangladesh J. Agril. Res. 41(1): 137-150, March 2016

\title{
TREND AND OUTPUT GROWTH ANALYSIS OF MAJOR FRUITS IN CHITTAGONG REGION OF BANGLADESH
}

\author{
M. JAMAL UDDIN ${ }^{1}$, S. R. DEY ${ }^{2}$ AND TAHMINA TASLIM ${ }^{3}$
}

\begin{abstract}
The study analyzed the trends, growth rates of area, production and yield of major fruits in Chittagong region and identified factors contributing to output growth during 1993/94-2009/10 using secondary data. The fruits under study were mango, jackfruit, litchi, guava, banana, papaya, ber, pomelo, pineapple, watermelon, lime and lemon. The study revealed that the area of all fruits increased over the period except banana, ber, pomelo and water melon. The highest increase in area was estimated for guava $(131.6 \%)$ and the lowest for jackfruit $(6.4 \%)$. Similarly, the production of all fruits over the period was increased except banana and pineapple. The average annual growth rates of area, production and yield for all fruits were found to be positive in all periods (i.e, period I: 1993/94-1997/98; Period II: 1998/99-2003/04, and Period III: 2004/052009/10). But the magnitude of the growth rates of area for all fruits varied significantly. The growth rates of area for mango, jackfruit, litchi and pineapple were increased impressively and significantly. This might be due to the adoption of improved variety and management practices by the farmers. The growth rate of area, production and yield of banana decreased drastically over the period due to absence of modern variety of banana and lack of improved management practices in the region. The growth rates of production for mango were found to be highest in the period III (2004/05-2009/10). But the growth rate of yield of mango was found to be decreased significantly over the periods due to improper management against the pest and diseases by the farmers. The highest percentage of output changed was observed in Banana (149\%) followed by pineapple (106\%) and jackfruit $(83 \%)$ between the periods. The lowest percentage of output changed was found in guava $(11.7 \%)$. The contribution of area was the highest in changing output for mango, jackfruit, litchi, guava, ber, pomelo, watermelon, lime and lemon. The contribution of yield was the highest for banana $(135.57 \%)$, papaya $(76.92 \%)$ and pineapple $(158.62 \%)$ for changing output indicated that the increased area was more responsible for changing in output growth of selected fruits. To increase the growth rate of fruits, improved variety and management practices should be disseminated through undertaking special programme and strengthening research-extension linkage in the Chittagong region.
\end{abstract}

Keywords: Trends, fruits, area, production, yield, output growth, Chittagong region.

${ }^{1}$ Senior Scientific Officer, RARS, Hathazari, Chittagong, ${ }^{2}$ Scientific Officer, Biotechnology Division, Bangladesh Agricultural Research Institute (BARI), Gazipur, ${ }^{3}$ Senior Assistant Chief, Industry and Energy Division, Planning Commission, Dhaka, Bangladesh. 


\section{Introduction}

Bangladesh is blessed with many horticultural crops. More than 90 vegetables, 60 fruits and 25 spices are being grown in the country. Fruits in Bangladesh cover an area of 242.8 thousand hectares with a total production of 10.91 lakh metric tons (BBS, 2012). Fruits play a unique role both in economic and social sphere for improving income and nutritional status, particularly rural masses. Fruits are highly valued in human diet mainly for vitamins and minerals. Along with these, orchards of fruits help in maintaining ecological balance. Fruit contributes $10 \%$ income of the national economy and 1-2\% land covered of the total cultivable land in Bangladeh (Mondal et al., 2011).

Per capita per day fruit intake is 44.7 gram at national level and that of 42.6 gram for rural areas (HIES, 2010) as compared to the minimum requirement of 100 g/capita (FAO/WHO, 2003; BAN-HRDB, 2007).

Due to tropical and subtropical climate, a variety of fruits and vegetables are grown in our country. Particularly, the distinctive climatic conditions in the Chittagong region provide a great diversity and variety for fruit production. The major fruits grown in the Chittagong region (Chittagong and Cox's Bazar districts) include mango, jackfruit, litchi, guava, banana, papaya, ber, pomelo, pineapple, watermelon, lime \& lemon. The area, total production and yield of major fruits grown in the region are shown in the Table1.

Table1. Area and production of major fruits in the Chittagong region, 2009-10

\begin{tabular}{c|l|c|c|c}
\hline $\begin{array}{c}\text { Sl. } \\
\text { No. }\end{array}$ & Fruits & $\begin{array}{c}\text { Area } \\
\text { (ha) }\end{array}$ & $\begin{array}{c}\text { Production } \\
(\mathrm{mt})\end{array}$ & $\begin{array}{c}\text { Yield } \\
(\mathrm{t} / \mathrm{ha})\end{array}$ \\
\hline 1 & Mango & 2262 & 16366 & 8.82 \\
2 & Jackfruit & 1312 & 50635 & 38.59 \\
3 & Litchi & 304 & 1932 & 6.36 \\
4 & Guava & 1126 & 30763 & 2733 \\
5 & Banana & 1417 & 16011 & 11.30 \\
6 & Papaya & 413 & 3737 & 9.05 \\
7 & Ber & 94 & 3763 & 39.89 \\
8 & Pomelo & 302 & 3556 & 11.79 \\
9 & Pineapple & 1091 & 12712 & 11.66 \\
10 & Watermelon & 1351 & 22159 & 1641 \\
11 & Lime \& lemon & 416 & 6286 & 1512 \\
\hline
\end{tabular}

Source: (BBS, 2012).

Currently, export of fruits is considered to be a big source of foreign earning exchange. The region produces a million tons of fruits annually. That is why, this 
region is rightly considered to be a fruit basket of Bangladesh. An analysis of fluctuations of fruit production, productivity apart from growth, is of importance for understanding the status of fruit development in the region. The magnitude of fluctuations depends on fruit production technology, its sensitivity to weather, economic environment, availability of inputs and many other associated factors.

The growth rate of area, production and yield of fruits could help to facilitate, the forecasting on the future development of fruits in the region. Therefore, the findings of the study are of great importance for horticulturist, researcher, extension workers, and policy makers for improving fruit production in the region.

The specific objectives of the study were:

i) to analyze the trends in average area, production and productivity of major fruits grown in the Chittagong region during 1993/94 - 2009/10;

ii) to estimate the annual growth rates of area, production, and yield of major fruits in the Chittagong region during 1993/94 - 2009/10;

iii) to identify the contribution of area, yield and interaction of yield and area in output growth of the selected fruits; and

iv) to derive policy implications from the above.

\section{Methodology}

This study was carried out based on secondary data sources i.e. different issues of BBS and other published scientific articles and journals. The data period was 1993/94 to 2009/10 (16 years). The selected fruits were mango, jackfruit, litchi, guava, banana, papaya, ber, pomelo, pineapple, watermelon, lime and lemon. The BBS authority collected time series data on mango and jackfruit for the period of 06 years (2004-05 to 2009-10) in a different way. So, for getting unbiased and meaningful results of the growth rates, the data was analysed on disaggregated manner i.e. \{Period I (1993/94-1997/98); Period II (1998/99-2003/04, and Period III (2004/05-2009/10)\}. The descriptive analyses were done for estimating the trend of area, production and yield of the selected fruits.

In the study compound growth rate (CGR) analysis was used. It is usually estimated by fitting a semi-log trend equation (repeated) of the following form CGRs of area, production and yield of the selected fruits (Gujarati, 1988:

$\mathrm{Y}=\mathrm{a} \cdot \mathrm{e}^{\mathrm{bti}}$

Or In $\mathrm{Y}=$ Ina+bti

Or $\operatorname{InY}=\mathrm{A}+$ bti (here $\mathrm{A}=\mathrm{Ina}$ )

Where,

$\mathrm{A}=$ Intercept

$\mathrm{Y}=$ Quantity of major fruits production, area and yield 
$\mathrm{b}=$ Growth rate in ratio scale and when multiplied by 100 , it express $\%$ age growth i.e, annual growth rate

$\mathrm{ti}=$ Time, $\mathrm{i}=1,2,3, \ldots \ldots \ldots \ldots, 16$ years

In $=$ Natural log of the variable

The slop coefficient ' $b$ ' measures the instantaneous rate of growth. The compound growth rate ' $r$ ' may be calculated as follow:

CGR (r) = (antilog of $\mathrm{b}-1) \times 100$

The above mentioned equation was estimated by applying OLS method. The standard error was applied to test the significance of ' $b$ '. This equation is generally used on the consideration that changes in agricultural area or output or yield in a given year would depend upon the area or output or yield in the preceding year (Deosthali and chandrathekhar, 2014).

For estimating the contributing factors on fruit output, the decomposition analyses were used:

Decomposition analysis: To decompose the components of change in major fruits production and their contributions, the following algebric equation is estimated (Kamruzzaman et al., 1998):

Change in total production

$$
\mathrm{P}_{\mathrm{t}}-\mathrm{P}_{0}=
$$

Contribution of area change

$$
\mathrm{Y}_{0}\left[\mathrm{~A}_{\mathrm{t}}\left(1+\mathrm{C}_{0}-\mathrm{C}_{\mathrm{t}}\right)-\mathrm{A}_{0}\right]+
$$

(Absolute change in area)

Contribution of yield change

$$
\left[A_{t}\left\{1+\left(C_{0}-C_{t}\right)\left(Y_{t}-Y_{0}\right)\right\}\right]
$$

Where, $\mathrm{P}_{0}=$ production of the respective fruit in 1993/94

$\mathrm{P}_{\mathrm{t}}=$ production of the respective fruit in 2009/10

$\mathrm{A}_{0}=$ area under the fruit in 1993/94

$\mathrm{A}_{\mathrm{t}}=$ area under the fruit in 2009/10

$\mathrm{Y}_{0}=$ the yield of respective fruit in 1993/94

$Y_{t}=$ the yield of respective fruit in 2009/10

$\mathrm{C}_{0}=$ the proportion of area under the fruit to gross fruit production area under all fruits in 1993/94

$\mathrm{C}_{\mathrm{t}}=$ the proportion of area under the fruit to gross fruit production area under all fruits in 2009/10.

\section{Results and Discussion}

\section{Trends in average area, production and yield of major fruits}

During the period, the area of all fruits increased except banana, ber, pomelo and water melon and these were decreased negatively. The highest increase in area was 
recorded for guava (131.67\%), while the lowest for jackfruit (6.4\%). Ber fruit recorded the highest decrease in area, while the lowest decrease was in pomelo $(0.67 \%)$ (Table 2$)$. The average production of all fruits increased except banana and pineapple. They were negatively decreased in production over the period. The highest increase in production was recorded for guava $(754.53 \%)$ while the lowest for jackfruit (20.29\%) (Table 2). The average yield of all fruits increased except banana and pineapple over the base year (1993/94). Yield of all fruits was lower than national average except pineapple and water melon.

Table 2. Percentage change in area, production and yield of major fruits in Chittagong region over the period of 1993/94 to 2009/10

\begin{tabular}{|c|c|c|c|c|c|c|c|}
\hline $\begin{array}{l}\text { Sl. } \\
\text { No. }\end{array}$ & Fruits & $\begin{array}{c}\text { Average } \\
\text { area (ha) } \\
\text { over } \\
1993 / 94 \\
\text { to } \\
2009 / 10\end{array}$ & $\begin{array}{c}\text { Percentage } \\
\text { change in } \\
\text { area over } \\
1993 / 94 \text { to } \\
2009 / 10\end{array}$ & $\begin{array}{c}\begin{array}{c}\text { Average } \\
\text { production } \\
\text { (tons) }\end{array} \\
\text { over } \\
1993 / 94 \text { to } \\
2009 / 10\end{array}$ & $\begin{array}{c}\text { Percentage } \\
\text { change in } \\
\text { production } \\
\text { over } \\
1993 / 94 \text { to } \\
2009 / 10\end{array}$ & $\begin{array}{c}\text { Average } \\
\text { yield } \\
\text { (ton/ha) } \\
\text { over } \\
1993 / 94 \\
\text { to } \\
2009 / 10\end{array}$ & $\begin{array}{l}\text { Percentage } \\
\text { change in } \\
\text { yield over } \\
1993 / 94 \text { to } \\
2009 / 10\end{array}$ \\
\hline 1 & Mango & 2181 & 7.15 & 13284 & 106.41 & 6.04 & 92.64 \\
\hline 2 & Jackfruit & 1253 & 6.40 & 11848 & 20.39 & 9.46 & 13.15 \\
\hline 3 & Litchi & 280 & 12.78 & 1346 & 100.21 & 4.75 & 77.72 \\
\hline 4 & Guava & 1184 & 131.67 & 14784 & 754.53 & 13.47 & 268.86 \\
\hline 5 & Banana & 1672 & -14.75 & 20217 & -37.12 & 12.21 & -26.24 \\
\hline 6 & Papaya & 313 & 68.60 & 2261 & 119.18 & 7.19 & 30.00 \\
\hline 7 & Ber & 323 & -57.64 & 2733 & 263.57 & 12.05 & 758.22 \\
\hline 8 & Pomelo & 369 & -0.67 & 2202 & 397.37 & 6.23 & 400.68 \\
\hline 9 & Pineapple & 838 & 48.43 & 12665 & -6.43 & 15.54 & -36.96 \\
\hline 10 & Watermelon & 1454 & -10.08 & 17550 & 55.83 & 12.21 & 73.03 \\
\hline 11 & $\begin{array}{l}\text { Lime } \\
\text { lemon }\end{array}$ & 265 & 65.65 & 2323 & 461.25 & 11.12 & 238.83 \\
\hline
\end{tabular}

Source: BBS (2001 to 2010).

\section{Growth rate of area of major fruits}

The average annual growth rates of area for all fruits were found to be positive in all periods. But the magnitudes of the growth rates varied significantly among the fruits as well as over the period. The growth rates of area for mango and litchi was found to be highest in period III (2004/05-2009/10) as compared to other two periods. This might be due to adopt improved varieties of mango is and litchis as a profitable fruits. But the growth rates of area for jackfruit and pineapple was the highest in the period I (1993/94-1997/98) as compared to next two periods. The 
growth rates of area for others fruits were found to be lower over the three periods (Table 2, Table 5 and Table 8 and Figure 4). Reasons for increased growth rates of area of fruits might be accelerated to create awareness and profitability of those fruits.

\section{Growth rates of production of major fruits}

The average annual growth rates of production for all fruits were found to be positive in all periods. But the magnitudes of the growth rates of production for all fruits were varied insignificantly. The growth rates of production for mango were found to be highest in the period III (2004/05-2009/10) compared to other two periods. But the growth rates of production for jackfruit and pineapple were the highest in period I (1993/94-1997/98) compared to next two periods. The growth rate of production of litchi was found to be increased significantly over the periods. This might be due to adopt improved varieties of litchi as a profitable fruit. But the growth rate of production of banana fluctuated over the periods. The growth rate of production of banana decreased drastically in the period III. This may be due to decrease the area of banana and might be most of the farmers were highly motivated to be planted mango and litchi as an economic fruit. The growth rates of production for others fruits were found to be fluctuated over the three periods (Table 2, Table 3, Table 6 and Table 9). Reasons for increased and decreased growth rates might be accelerated to create awareness and profitability of those fruits.

\section{Growth rates of yield of major fruits}

The average annual growth rates of yield for all fruits were found to be positive in all periods. But the magnitudes of the growth rates of yield for all fruits were varied significantly. The highest growth rate of yield for mango was obtained in the period I (2004/05-2009/10) as compared to other two periods. But the growth rate of yield for mango was found to be decreased gradually over the periods. This might be happened due to improper management against the pest and diseases by the farmers. Similarly, the growth rate of yield of jackfruit was found to be decreased gradually over the periods might be the same reasons. On the other hand, the growth rate of yield of litchi was recorded to be increased over the period. This might be happened due to introduce improved variety of litchi at farmers level. Notably, the growth rate of yield of guava was found to be decreased drastically over the periods. The growth rate of yield of banana was found to be fluctuated over the period but drastically decreased in the current period i.e 2004/05 -2009/10. This might be happened due to absence of modern varieties of bananas and lack of improved management practices. The growth rates of yield for other fruits were found to be fluctuated over the three periods (Table 4, Table 7 and Table 10). Reasons for increased and decreased growth rates of yield might be accelerated to 
adopt modern varieties and improved management practices. The growth rate of yield of watermelon was found to be highest in the period I (i.e. 1993/94 -1997/98). But the growth rate of yield of watermelon was decreased drastically in the next two periods. This might be due to severe disease and improper management by the farmers.

Table 3. Average annual growth rates of area of major fruits in Chittagong region, Period I (1993/94-1997/1998

\begin{tabular}{c|l|c|c|c|c|c}
\hline $\begin{array}{r}\text { Sl. } \\
\text { No. }\end{array}$ & Fruits & Intercept & $\begin{array}{c}\text { Compound } \\
\text { Growth Rate }(\%)\end{array}$ & t-ratio & P-value & $\mathrm{R}^{2}$ \\
\hline 1 & Mango & 8.55 & 65.26 & $4.59^{* *}$ & 0.04 & 0.91 \\
2 & Jackfruit & 8.02 & 96.65 & $1.65^{\text {ns }}$ & 0.24 & 0.57 \\
3 & Litchi & 6.49 & 48.04 & $0.15^{\text {ns }}$ & 0.89 & 0.11 \\
4 & Guava & 7.09 & 4.41 & $3.03^{*}$ & 0.09 & 0.82 \\
5 & Banana & 8.31 & 21.7 & $0.92^{\text {ns }}$ & 0.45 & 0.30 \\
6 & Papaya & 6.41 & 1.10 & $1.61^{\text {ns }}$ & 0.24 & 0.56 \\
7 & Ber & 6.30 & 0.73 & $17.57^{* * *}$ & 0.00 & 0.99 \\
8 & Pomelo & 6.62 & 12.22 & $2.65^{\text {ns }}$ & 011 & 0.77 \\
9 & Pineapple & 7.50 & 47.53 & $0.58^{\text {ns }}$ & 0.61 & 0.14 \\
10 & Watermelon & 8.21 & 14.31 & $7.71^{* *}$ & 0.01 & 0.96 \\
11 & Lime \& lemon & 6.42 & 17.05 & $2.13^{\text {ns }}$ & 0.16 & 0.69 \\
\hline
\end{tabular}

Note: $* * *=$ Significant at $1 \%$ level; $* *=$ Significant at $5 \%$ level; * Significant at $10 \%$ level; and ns $=$ Not significant.

Table 4. Average annual growth rates of production of major fruits in Chittagong region, Period I (1993/94-1997/1998.

\begin{tabular}{c|l|c|c|c|c|c}
\hline $\begin{array}{r}\text { Sl. } \\
\text { No. }\end{array}$ & \multicolumn{1}{|c|}{ Fruits } & Intercept & $\begin{array}{c}\text { Compound } \\
\text { Growth Rate (\%) }\end{array}$ & t-ratio & P-value & $\mathrm{R}^{2}$ \\
\hline 1 & Mango & 9.17 & 13.6 & $1.29^{\text {ns }}$ & 0.32 & 0.45 \\
2 & Jackfruit & 9.32 & 42.5 & $0.32^{\text {ns }}$ & 0.77 & 0.49 \\
3 & Litchi & 6.87 & 6.19 & $0.33^{\text {ns }}$ & 0.76 & 0.15 \\
4 & Guava & 8.18 & 3.74 & $2.39^{\text {ns }}$ & 0.13 & 0.74 \\
5 & Banana & 10.14 & 12.33 & $1.59^{\text {ns }}$ & 0.25 & 0.56 \\
6 & Papaya & 7.44 & 1.31 & $1.72^{\text {ns }}$ & 0.21 & 0.62 \\
7 & Ber & 11.02 & 1.18 & $9.34^{* *}$ & 0.01 & 0.97 \\
8 & Pomelo & 6.57 & 3.89 & $3.33^{*}$ & 0.07 & 0.84 \\
9 & Pineapple & 9.51 & 20.17 & $2.35^{\text {ns }}$ & 0.14 & 0.73 \\
10 & Watermelon & 9.56 & 15.65 & $5.71^{* *}$ & 0.02 & 0.94 \\
11 & Lime \& lemon & 7.02 & 13.63 & $2.86^{*}$ & 0.10 & 0.80 \\
\hline
\end{tabular}

Note: $* *=$ Significant at $5 \%$ level; $*=$ Significant at $10 \%$ level; and ns= Not significant. 
Table 5. Average annual growth rates of yield of major fruits in Chittagong region, Period I (1993/94- 1997/1998

\begin{tabular}{c|l|c|c|c|c|c}
\hline $\begin{array}{r}\text { Sl. } \\
\text { No. }\end{array}$ & Fruits & Intercept & $\begin{array}{c}\text { Compound } \\
\text { Growth Rate }(\%)\end{array}$ & t-ratio & P-value & $\mathrm{R}^{2}$ \\
\hline 1 & Mango & 0.61 & 79.70 & $4.01^{* *}$ & 0.05 & 0.88 \\
2 & Jackfruit & 1.32 & 102.14 & $2.01^{\mathrm{ns}}$ & 0.18 & 0.67 \\
3 & Litchi & 0.37 & 88.66 & $0.63^{\mathrm{ns}}$ & 0.59 & 0.16 \\
4 & Guava & 1.09 & 16.60 & $1.45^{\mathrm{ns}}$ & 0.28 & 0.51 \\
5 & Banana & 1.82 & 25.65 & $1.69^{\mathrm{ns}}$ & 0.23 & 0.58 \\
6 & Papaya & 5.03 & 5.14 & $1.15^{\mathrm{ns}}$ & 0.36 & 0.40 \\
7 & Ber & 0.63 & 29.17 & $1.92^{\mathrm{ns}}$ & 0.19 & 0.64 \\
8 & Pomelo & -0.04 & 8.12 & $1.92^{\mathrm{ns}}$ & 0.19 & 0.64 \\
9 & Pineapple & 2.01 & 20.92 & $4.19^{* *}$ & 0.05 & 0.89 \\
10 & Watermelon & 1.34 & 152.46 & $2.45^{\mathrm{ns}}$ & 0.13 & 0.75 \\
11 & Lime \& lemon & 0.59 & 72.38 & $0.63^{\mathrm{ns}}$ & 0.59 & 0.16 \\
\hline
\end{tabular}

Note: $* *=$ Significant at $5 \%$ level; and ns= Not significant.

Table 6. Average annual growth rates of area of major fruits in Chittagong region, Period II (1998/99 - 2003/04.

\begin{tabular}{c|l|c|c|c|c|c}
\hline $\begin{array}{r}\text { Sl. } \\
\text { No. }\end{array}$ & Fruits & Intercept & $\begin{array}{c}\text { Compound } \\
\text { Growth Rate }(\%)\end{array}$ & t-ratio & P-value & $\mathrm{R}^{2}$ \\
\hline 1 & Mango & 8.57 & 88.72 & $0.38^{\mathrm{ns}}$ & 0.76 & 0.12 \\
2 & Jackfruit & 8.02 & 28.20 & $14.75^{* * *}$ & 0.00 & 0.99 \\
3 & Litchi & 6.46 & 49.00 & $22.76^{* *}$ & 0.02 & 0.99 \\
4 & Guava & 7.50 & 5.50 & $1.85^{\mathrm{ns}}$ & 0.31 & 0.77 \\
5 & Banana & 8.37 & 67.50 & $0.53^{\mathrm{ns}}$ & 0.68 & 0.22 \\
6 & Papaya & 6.77 & 24.98 & $0.92^{\mathrm{ns}}$ & 0.52 & 0.45 \\
7 & Ber & 6.70 & 1.42 & $2.19^{\mathrm{ns}}$ & 0.27 & 0.82 \\
8 & Pomelo & 6.87 & 3.33 & $5.16^{\mathrm{ns}}$ & 0.12 & 0.96 \\
9 & Pineapple & 7.53 & 17.89 & $1.94^{\mathrm{ns}}$ & 0.30 & 0.79 \\
10 & Watermelon & 8.22 & 3.34 & $5.19^{\mathrm{ns}}$ & 0.12 & 0.96 \\
11 & Lime \& lemon & 6.52 & 2.36 & $2.29^{\mathrm{ns}}$ & 0.26 & 0.84 \\
\hline
\end{tabular}

Note: $* * *=$ Significant at $1 \%$ level; $* *=$ Significant at $5 \%$ level; and ns= Not significant. 
Table 7. Average annual growth rates of production of major fruits in Chittagong region, Period II (1998/99 -2003/04

\begin{tabular}{c|l|c|c|c|c|c}
\hline $\begin{array}{r}\text { Sl. } \\
\text { No. }\end{array}$ & Fruits & Intercept & $\begin{array}{c}\text { Compound } \\
\text { Growth Rate (\%) }\end{array}$ & t-ratio & P-value & $\mathrm{R}^{2}$ \\
\hline 1 & Mango & 11.43 & 16.98 & $1.63^{\text {ns }}$ & 0.34 & 0.72 \\
2 & Jackfruit & 9.32 & 26.87 & $5.63^{\text {ns }}$ & 0.11 & 0.96 \\
3 & Litchi & 6.82 & 8.38 & $0.94^{\text {ns }}$ & 0.51 & 0.47 \\
4 & Guava & 8.70 & 0.85 & $1.76^{\text {ns }}$ & 0.32 & 0.75 \\
5 & Banana & 9.89 & 29.17 & $0.80^{\text {ns }}$ & 0.56 & 0.39 \\
6 & Papaya & 7.73 & 34.76 & $0.04^{\text {ns }}$ & 0.97 & 0.16 \\
7 & Ber & 7.34 & 1.18 & $2.03^{\text {ns }}$ & 0.28 & 0.81 \\
8 & Pomelo & 7.02 & 20.38 & $0.33^{\text {ns }}$ & 0.79 & 0.99 \\
9 & Pineapple & 9.56 & 7.44 & $1.40^{\text {ns }}$ & 0.48 & 0.52 \\
10 & Watermelon & 9.54 & 7.34 & $3.11^{\text {ns }}$ & 0.19 & 0.90 \\
11 & Lime \& lemon & 7.06 & 7.18 & $6.12^{*}$ & 0.10 & 0.97 \\
\hline
\end{tabular}

Note: *=Significant at $10 \%$ level; and ns= Not significant.

Table 8. Average annual growth rates of yield of major fruits in Chittagong region, Period II (1998/99 - 2003/04.

\begin{tabular}{c|l|c|c|c|c|c}
\hline $\begin{array}{r}\text { Sl. } \\
\text { No. }\end{array}$ & Fruits & Intercept & $\begin{array}{c}\text { Compound } \\
\text { Growth Rate (\%) }\end{array}$ & t-ratio & P-value & $\mathrm{R}^{2}$ \\
\hline 1 & Mango & 0.58 & 8.16 & $1.25^{\mathrm{ns}}$ & 0.43 & 0.60 \\
2 & Jackfruit & 1.58 & 36.48 & $1.36^{\mathrm{ns}}$ & 0.40 & 0.64 \\
3 & Litchi & 3.51 & 3.73 & $0.41^{\mathrm{ns}}$ & 0.75 & 0.14 \\
4 & Guava & 1.20 & 1.57 & $2.06^{\mathrm{ns}}$ & 0.28 & 0.81 \\
5 & Banana & 1.52 & 47.01 & $1.13^{\mathrm{ns}}$ & 0.46 & 0.56 \\
6 & Papaya & 0.96 & 14.19 & $3.00^{\mathrm{ns}}$ & 0.20 & 0.90 \\
7 & Ber & 0.68 & 6.31 & $1.62^{\mathrm{ns}}$ & 0.35 & 0.72 \\
8 & Pomelo & 0.15 & 11.84 & $1.23^{\mathrm{ns}}$ & 0.43 & 0.60 \\
9 & Pineapple & 2.02 & 4.83 & $1.71^{\mathrm{ns}}$ & 0.33 & 0.74 \\
10 & Watermelon & 1.31 & 7.83 & $7.88^{*}$ & 0.08 & 0.98 \\
11 & Lime \& lemon & 0.53 & 2.94 & $2.07^{\mathrm{ns}}$ & 0.28 & 0.81 \\
\hline
\end{tabular}

Note: *=Significant at $10 \%$ level; and $\mathrm{ns}=$ Not significant. 
Table 9. Average annual growth rates of area of major fruits in Chittagong region, Period III (2004/05 - 2009/10

\begin{tabular}{rl|c|c|c|c|c}
\hline $\begin{array}{r}\text { Sl. } \\
\text { No. }\end{array}$ & \multicolumn{1}{c|}{ Fruits } & Intercept & $\begin{array}{c}\text { Compound } \\
\text { Growth Rate }(\%)\end{array}$ & t-ratio & P-value & $\mathrm{R}^{2}$ \\
\hline 1 & Mango & 8.63 & 94.90 & $1.86^{\mathrm{ns}}$ & 0.15 & 0.53 \\
2 & Jackfruit & 8.03 & 24.33 & $1.90^{\mathrm{ns}}$ & 0.15 & 0.54 \\
3 & Litchi & 6.61 & 57.58 & $2.37^{\mathrm{ns}}$ & 0.09 & 0.65 \\
4 & Guava & 7.68 & 14.49 & $3.34^{\mathrm{ns}}$ & 0.04 & 0.78 \\
5 & Banana & 8.39 & 2.39 & $2.80^{\mathrm{ns}}$ & 0.06 & 0.72 \\
6 & Papaya & 6.78 & 7.69 & $0.48^{\mathrm{ns}}$ & 0.65 & 0.07 \\
7 & Ber & 6.73 & 0.72 & $1.94^{\mathrm{ns}}$ & 0.14 & 0.55 \\
8 & Pomelo & 6.76 & 3.63 & $3.03^{\mathrm{ns}}$ & 0.05 & 0.75 \\
9 & Pineapple & 7.37 & 14.92 & $1.66^{\mathrm{ns}}$ & 0.19 & 0.48 \\
10 & Watermelon & 8.14 & 20.45 & $0.54^{\mathrm{ns}}$ & 0.62 & 0.08 \\
11 & Lime \& lemon & 5.73 & 1.72 & $0.02^{* *}$ & 0.98 & 0.06 \\
\hline
\end{tabular}

Note: $* *=$ Significant at $5 \%$ level; and ns= Not significant.

Table 10. Average annual growth rates of production of major fruits in Chittagong region, Period III (2004/05-2009/10).

\begin{tabular}{c|l|c|c|c|c|c}
\hline $\begin{array}{r}\text { Sl. } \\
\text { No. }\end{array}$ & \multicolumn{1}{|c|}{ Fruits } & Intercept & $\begin{array}{c}\text { Compound } \\
\text { Growth Rate }(\%)\end{array}$ & t-ratio & P-value & $\mathrm{R}^{2}$ \\
\hline 1 & Mango & 9.89 & 24.51 & $2.46^{*}$ & 0.09 & 0.66 \\
2 & Jackfruit & 9.43 & 12.28 & $1.95^{\mathrm{ns}}$ & 0.14 & 0.56 \\
3 & Litchi & 15.65 & 12.00 & $1.40^{\mathrm{ns}}$ & 0.25 & 0.39 \\
4 & Guava & 9.91 & 3.26 & $3.34^{*}$ & 0.04 & 0.79 \\
5 & Banana & 9.87 & 5.91 & $0.94^{\mathrm{ns}}$ & 0.41 & 0.23 \\
6 & Papaya & 8.17 & 2.96 & $1.85^{\mathrm{ns}}$ & 0.15 & 0.53 \\
7 & Ber & 8.70 & 1.34 & $1.43^{\mathrm{ns}}$ & 0.24 & 0.40 \\
8 & Pomelo & 9.09 & 5.10 & $0.61^{\mathrm{ns}}$ & 0.58 & 0.10 \\
9 & Pineapple & 9.01 & 3.68 & $3.33^{* *}$ & 0.04 & 0.78 \\
10 & Watermelon & 10.12 & 17.97 & $0.70^{\mathrm{ns}}$ & 0.53 & 0.14 \\
11 & Lime \& lemon & 7.95 & 0.73 & $7.43^{* * *}$ & 0.00 & 0.94 \\
\hline
\end{tabular}

Note: $* * *=$ Significant at $1 \%$ level; $* *=$ Significant at $5 \%$ level; $*=$ Significant at $10 \%$ level; and $n s=$ Not significant. 
Table 11. Average annual growth rates of yield of major fruits in Chittagong region, Period III (2004/05 -2009/10

\begin{tabular}{c|l|c|c|c|c|c}
\hline $\begin{array}{r}\text { Sl. } \\
\text { No. }\end{array}$ & Fruits & Intercept & $\begin{array}{c}\text { Compound Growth } \\
\text { Rate }(\%)\end{array}$ & t-ratio & P-value & $\mathrm{R}^{2}$ \\
\hline 1 & Mango & 1.25 & 4.75 & $2.47^{*}$ & 0.09 & 0.66 \\
2 & Jackfruit & 1.39 & 24.96 & $1.91^{\mathrm{ns}}$ & 0.15 & 0.54 \\
3 & Litchi & 0.74 & 7.92 & $0.64^{\mathrm{ns}}$ & 0.56 & 0.12 \\
4 & Guava & 2.23 & 1.96 & $5.24^{* * *}$ & 0.01 & 0.90 \\
5 & Banana & 1.48 & 4.23 & $1.37^{\mathrm{ns}}$ & 0.26 & 0.38 \\
6 & Papaya & 1.39 & 3.38 & $1.11^{\mathrm{ns}}$ & 0.34 & 0.29 \\
7 & Ber & 1.97 & 0.37 & $3.53^{* *}$ & 0.03 & 0.81 \\
8 & Pomelo & 1.33 & 2.78 & $1.56^{\mathrm{ns}}$ & 0.21 & 0.45 \\
9 & Pineapple & 1.63 & 6.43 & $1.83^{\mathrm{ns}}$ & 0.16 & 0.52 \\
10 & Watermelon & 1.97 & 10.87 & $4.02^{* *}$ & 0.02 & 0.84 \\
11 & Lime \& lemon & 2.23 & 1.44 & $0.97^{\mathrm{ns}}$ & 0.40 & 0.23 \\
\hline
\end{tabular}

Note: $* * *=$ Significant at $1 \%$ level; $* *=$ Significant at $5 \%$ level; $*=$ Significant at $10 \%$ level; and ns $=$ Not significant.

Table 12. Summary of annual growth rate (\%) of major fruits in the Chittagong region

\begin{tabular}{l|ccc|c|c|c|c|c|c}
\hline \multirow{2}{*}{ Fruits } & \multicolumn{3}{c|}{ Period I } & \multicolumn{3}{c|}{ Period II } & \multicolumn{3}{c}{ Period III } \\
\cline { 2 - 10 } & \multicolumn{1}{c}{$1993 / 94-1997 / 1998$} & \multicolumn{2}{c}{$1998 / 99-2003 / 04$} & \multicolumn{3}{c}{$2004 / 05-2009 / 10$} \\
\cline { 2 - 10 } Mrea & Prod. & Yield & Area & Prod. & Yield & Area & Prod. & Yield \\
\hline Mango & 65.3 & 13.6 & 79.7 & 88.7 & 17.0 & 8.2 & 94.9 & 24.5 & 4.8 \\
Jackfruit & 96.7 & 42.5 & 102.1 & 28.2 & 26.9 & 36.5 & 24.3 & 12.3 & 25.0 \\
Litchi & 48.0 & 6.2 & 88.7 & 49.0 & 8.4 & 3.7 & 57.6 & 12.0 & 7.9 \\
Guava & 4.4 & 3.7 & 16.6 & 5.5 & 0.9 & 1.6 & 14.5 & 3.3 & 2.0 \\
Banana & 21.7 & 12.3 & 25.7 & 67.5 & 29.2 & 47.0 & 2.4 & 5.9 & 4.2 \\
Papaya & 1.1 & 1.3 & 5.1 & 25.0 & 34.8 & 14.2 & 7.7 & 3.0 & 3.4 \\
Ber & 0.7 & 1.2 & 29.2 & 1.4 & 1.2 & 6.3 & 0.7 & 1.3 & 0.4 \\
Pomelo & 12.2 & 3.9 & 8.1 & 3.3 & 20.4 & 11.8 & 3.6 & 5.1 & 2.8 \\
Pineapple & 47.5 & 20.2 & 20.9 & 17.9 & 7.4 & 4.8 & 14.9 & 3.7 & 6.4 \\
Watermelon & 14.3 & 15.7 & 152.5 & 3.3 & 7.3 & 7.8 & 20.5 & 18.0 & 10.9 \\
Lime \& & 17.1 & 13.6 & 72.4 & 2.4 & 7.2 & 2.9 & 1.7 & 0.7 & 1.4 \\
lemon & & & & & & & & & \\
\hline
\end{tabular}

\section{Decomposition of output growth of individual fruits}

The sources of output change between two periods might be due to the change in area, yield and the multiplicative effects of the both. The relative contribution of 
area, yield, and their interaction to change the production of individual fruit is presented in Table 13. Results revealed that among the fruits, the highest percentage of output changed was observed in banana (149\%) followed by pineapple $(106 \%)$ and jackfruit $(83 \%)$ between the two periods. The lowest percentage of output changed was found in guava (11.7\%) between the two periods. The contribution of area was the highest in changing output between two periods for mango, jackfruit, litchi, guava, ber, pomelo, watermelon, lime and lemon. On the other hand, the contribution of yield was the highest for banana $(135.57 \%)$, papaya $(76.92 \%)$ and pineapple $(158.62 \%)$ for changing output between the periods. It indicated that the increased area was more responsible for changing in output growth of selected fruits between the two periods.

Table 13. Sources of change in output growth of the selected fruits in between 1993/94 and 2009/10.

\begin{tabular}{l|l|c|c|c|c|c}
\hline $\begin{array}{c}\text { Sl. } \\
\text { No. }\end{array}$ & Fruits & $\begin{array}{c}\text { Changes in } \\
\text { output } \\
\text { between the } \\
\text { periods (\%) }\end{array}$ & $\begin{array}{c}\text { Contribution } \\
\text { of area (\%) }\end{array}$ & $\begin{array}{c}\text { Contribution } \\
\text { of yield }(\%)\end{array}$ & $\begin{array}{c}\text { Interaction } \\
\text { between } \\
\text { yield and } \\
\text { area } \\
(3)\end{array}$ & $\begin{array}{c}\text { Total } \\
(\%)\end{array}$ \\
\hline 1. & Mango & 48.44 & 93.32 & 51.91 & -45.23 & 100 \\
2. Jackfruit & 83.06 & 93.98 & 88.38 & -82.36 & 100 \\
3. & Litchi & 49.95 & 88.67 & 56.33 & -45.00 & 100 \\
4. & Guava & 11.70 & 43.17 & 27.11 & 29.72 & 100 \\
5. & Banana & 149.04 & 117.32 & 135.57 & -152.89 & 100 \\
6. & Papaya & 45.62 & 59.31 & 76.92 & -36.23 & 100 \\
7. & Ber & 27.50 & 236.05 & 11.65 & -147.7 & 100 \\
8. & Pomelo & 20.11 & 100.67 & 19.97 & -20.64 & 100 \\
9. & Pineapple & 106.86 & 67.37 & 158.62 & -125.99 & 100 \\
10. & Watermelon & 64.17 & 111.21 & 57.70 & -68.91 & 100 \\
11. & Lime \& lemon & 17.82 & 60.37 & 29.91 & 9.72 & 100 \\
\hline
\end{tabular}

\section{Conclusions}

It may be concluded that the average annual growth rates of area, production and yield was found to be positive for all the selected fruits. But the magnitude of the growth rate was varied significantly among the fruits. Increased in area rather than yield of individual fruit was mostly responsible for changing the output growth significantly between the periods. Reasons for increased the growth rates might be accelerated to create awareness and profitability of those fruits. Similarly, reasons for lower growth rates of the selected fruits might be responsible for lower adoption of improved varieties and lack of improved management practices. So, 
there is a scope for enhancing productivity of all major fruits grown in the Chittagong region.

\section{Recommendations and policy implications}

Based on the above findings, the following recommendations and policy implications are made accordingly:

In view of protecting the decreasing trend of land allocation to banana, ber, pomelo, watermelon, lime and lemon, Government of Bangladesh and concerned departments at first should look out the causes of decreasing trend of land allocation of those fruits. Secondly, improved fruit technology so far existing in the country should be disseminated throughout the Chittagong region by strengthening research and extension linkage. In order to increase the production of banana, improved variety (BARI Kola 3 and BARI Kola 4) and management practices could be disseminated through undertaking special programme. Concerned department i.e. Department of Agriculture Extension (DAE), Bangladesh Agriculture Development Corporation (BADC) and Bangladesh Agricultural Research Institute (BARI) can play crucial role in disseminating the technology throughout the Chittagong region. Year round pineapple production technology developed by BARI can reduce the lower growth rate. The yield of pineapple could be enhanced through applying recommended doses of fertilizer and maintained intercultural operation regularly. Training should be needed in this aspect. The lower growth rate of production for, ber, pomelo, lemon and papaya can be increased by the adoption of improved variety and management practices at farmers' level throughout the Chittagong region. The DAE, BARI, BADC, NGO can play vital role for disseminating the technologies at farm level. The lower growth rates of yield of other fruits can also be increased at the same way.

\section{References}

BBS. 2012. Year Book of Agricultural Statistics of Bangladesh 2010. Bangladesh Bureau of Statistics, Statistics Division, Ministry of Planning, Government of the People's Republic of Bangladesh. www.bbs.gov.bd

BAN-HRDB. 2007. Bangladesh Applied Nutrition and Human Resource Development Board [Cited by Haque, M.A. 2010. Role of Indigenous Fruits in Food and Nutritional Securities in Bangladesh, Keynote speech presented at the National Workshop, BARC, Dhaka, Bangladesh, 16 June 2010].

Gujarati, D. N. 1988. Basic Econometrics. $2^{\text {nd }}$ e. McGraw Hill New York.

Deothali, V. and M. N. Chamdrashekhar, 2004. Rice: Regionwise Growth Trends in Maharastra. Economic \& Political weekly. Vol. 39, No. 03, January.

FAO/WHO. 2003. Diet, nutrition and the prevention of chronic diseases. Report of a Joint FAO/WHO Expert Consultation. WHO Technical Report Series 916. Geneva, World Health Organization. 
HIES. 2010. Report of the Household Income and Expenditure Survey, Bangladesh Bureau of Statistics, Planning Division, Ministry of Planning, Dhaka, Bangladesh.

Kamruzzaman, M. Joynal Abedin and M. A. Baset. 1998. Growth analysis of oilseeds, pulses and potatoes and factors contributing to their production. Bangladesh J. Agril. Res. 23(3): 491-508.

Mondal, M. R. Islam, M. S. Islam, M. A. J. Bhuiyan, M. M. Rahman, M. S. Alam and M. H. H. Rahman. 2011. Khrishi Projukti Hatboi (Hand Book of Agro-technology) (Part2), $5^{\text {th }}$ ed. Bangladesh Agricultural Research Institute, Joydebpur, Gazipur. P. 1. 